\title{
A MODEL FOR MOBILE LEARNING SERVICE QUALITY IN UNIVERSITY ENVIRONMENT
}

By

NABEEL FAROUQ ARIF AL-MUSHASHA

Theses Submitted to the Graduate Department of Information Technology College of Arts and Sciences, University Utara Malaysia, in Fulfillment of the Requirement for the Degree of Doctor of Philosophy 


\section{PERMISSION TO USE}

In presenting this thesis in fulfillment of the requirements for a postgraduate degree from University Utara Malaysia, I agree that the University library may make it freely available for inspection. I further agree that permission for copying of this thesis in any manner, in whole or part, for scholarly purposes may be granted by my supervisor(s) or, in their absence, by the Dean of College of Arts and Sciences. It is understood that any copying or publication or use of this thesis or parts thereof for financial gain shall not be allowed without my written permission. It is also understood that due recognition shall be given to me and to University Utara Malaysia for any scholarly use which may be made of any material from my thesis.

Requests for permission to copy or to make other use of materials in this thesis, in whole or in part should be addressed to:

Dean (Research and post graduate studies)

College of Arts and Sciences

(Department of Information Technology)

University Utara Malaysia

06010 UUM Sintok

Kedah Darul Aman 


\section{ABSTRACT}

Owing to the rapid development in the field of technology, there is a growing interest in e-learning. However, there are many limitations to it which includes accessibility and mobility that makes educationalists and researchers think of $m$ learning as a potential alternative tool for providing easy and accessible educational service. Nevertheless, there is a lack of research that addresses the issue of mobile learning service quality in a university environment. Therefore, this study aims to propose a service quality model for m-learning in a university environment. In order to accomplish this, a study was carried out to identify students' perception about mlearning services, and the factors that lead to service quality of m-learning in a university environment. Consequently, the researcher developed and implemented an mlearning system prototype (MLS) in a university environment. This research was conducted in three phases. The first phase was to obtain information about students' perception on m-learning services by conducting a 25- item questionnaire on 97 university students that were randomly selected from different colleges in University Utara Malaysia (UUM). The questionnaire measured six parameters which include the availability of devices, the usage of devices, students' attitude towards technology, students' opinions about prices of hardware, usage and perception about e-learning, and usage and perception about m-learning. The findings revealed that mobile phone is the most acceptable technology device among the university students, and students who have a positive attitude toward e-learning are likely to have positive attitude toward mlearning. In addition, it was found that obtaining the educational content is the most important m-learning service. Furthermore, high prices of the mobile services and devices minimize the utilization of mobile learning services. The second phase was meant to identify the factors that lead to service quality of m-learning in a university environment. The researcher administered a 57-item-questionnaire on 258 students representing different colleges of UUM. The questionnaire measured ten dependent variables and three independent variables. The dependent variables were meant to measure service quality (interface design, reliability, responsiveness, trust, and personalization), information quality (content usefulness, content adequacy), and system quality (ease of use, accessibility, and interactivity). The dependent variables were meant to measure the causal relationship between overall learners' perceived service quality, learner satisfaction, and learner behavioral intention to use the service in future. In order to analyze the obtained data, the researcher used structured equation modeling and exploratory factor analysis (EFA). The findings revealed that the factors that lead to service quality of m-learning in a university environment were interface design, reliability; trust, content usefulness, content adequacy, ease of use, accessibility, and interactivity. The third phase was carried out to implement the findings of the above two phases and present a practical example that reflects the dimensions of mobile learning service quality in a university environment. To accomplish this, the researcher developed the m-learning system prototype (MLSP) using Rapid Application Development (RAD) methodology and object-oriented (OO) approach. This prototype has been developed, tested and implemented at University Utara Malaysia (UUM). The MLSP was evaluated by employing usability testing method; the field experiments based on the standard tests followed by questionnaire. The findings of the whole study revealed that learners' overall perception about mobile learning service quality is strongly related to their service' satisfaction which positively affects their behavioral intentions in using mobile learning service in the future. 


\section{ACKNOWLEDGEMENTS}

By the name of ALLAH and mercy, the more you learn, the more you realize how little you know. We come to understand that our accomplishments are not possible without the help of ALLAH. The following are just a few of the countless people who have helped me to complete my Ph.D. studies.

I will always be especially thankful to my Ph.D. advisor, Assoc. Prof. Dr. Shahizan Hassan, for his guidance, patience, and faith in me. He was always positive, supportive, and encouraging. He fostered my academic growth by challenging and inspiring me to reach deeper, to learn more, to expand my viewpoint, and to think critically. Yet, he allowed me to express my views openly and to disagree even when I was wrong.

Also I would like to extend my special thanks to all members of CAS and other Colleges members who helped me in so many different ways. 


\section{DEDICATION}

To My Mother, Nida'a, and my Father Farouq, who gave me life, constantly inspired me, had unending faith in me, and nourished a passion for learning. Who indulged me for endless hours on numerous occasions with memorable conversations and lessons that have lasted a lifetime.

To my best friend and my biggest fan, my wife. Completion of a Ph.D. program was only possible because of her unwavering faith, sacrifice, support, and help.

For my childrens Farah, Ayah: Let this accomplishment inspire you always to pursue your own dreams and ambitions with the assurance that fulfillment is possible.

To my friend and best brother Ashraf, for his support and encourage during all stages of my Ph.D. work.

To my Uncle Hassan, the kindest person I ever knew who taught me many things that no one else even considered. 


\section{TABLE OF CONTENTS}

PERMISSION TO USE

$\begin{array}{lll}\text { ABSTRACT } & \text { iii }\end{array}$

ACKNOWLEDGEMENT

DEDICATION $\quad$ v

LIST OF APPENDIXES Xiii

LIST OF TABLES xiv

LIST OF FIGURES Xvi

LIST OF ABBREVIATION xviii

\section{CHAPTER ONE: INTRODUCTION}

$\begin{array}{lll}1.1 & \text { Introduction } & 1\end{array}$

1.2 Problem Statement 4

1.3 Research Questions $\quad 8$

$\begin{array}{lll}1.4 & \text { Research Objectives } & 8\end{array}$

$1.5 \quad$ Significance of the Research 9

$\begin{array}{lll}1.6 & \text { Scope of Study } & 10\end{array}$

$1.7 \quad$ General Research Framework 10

$\begin{array}{lll}1.8 & \text { Outline of the Thesis } & 13\end{array}$

CHAPTER TWO: LITERATURE REVIEW

2.1 Distance Learning (D-Learning) 16

$2.2 \quad$ Electronic Learning (E-Learning) 17

$2.3 \quad$ Mobile Learning (M-Learning) Service 19

2.3.1 The Implication of M-Learning Services 25

2.3.2 Differences between M-Learning and E-Learning 28

2.3.3 The Implication of M-Learning Services on the Research 30

$2.4 \quad$ Trends of Mobile Learning Services in Higher Education 31 
2.4.1 Wireless Coverage in Higher Education 33

2.4.2 Mobile Wireless Devices Used in Higher Education 33

2.4.2.1 Mobile Wireless Computers 33

2.4.2.2 Personal Digital Assistants (PDAs) 34

2.4.2.3 Mobile Wireless Phones 35

2.4.2.4 Short Message Services (SMS) and Multimedia 35 Services (MMS)

2.4.3 Benefits of Using Mobile Wireless Technologies in Higher 36 Education

2.4.3.1 Benefits of Mobile Wireless Computers 36

2.4.3.2 Benefits of PDAs 37

2.4.3.3 Benefits of Mobile Wireless Phones 38

2.4.4 The Implications of the Trends of M-learning Services in $\quad 40$ Higher Education on the Research

2.5 Service and Service quality 41

2.5.1 Introduction 41

2.5.2 Conceptualization of Service Quality 41

2.5.3 Criticism of SERVQUAL 48

2.5.4 Other Theories and Dimensions of Service Quality 50

2.5.5 The implication of Service Quality on the Research 53

2.6 Chapter Conclusion 53

\section{CHAPTER THREE: STUDENTS' PERCEPTION OF MOBILE LEARNING SERVICES: AN INITIAL STUDY}

3.1 Introduction 55

3.2 Study Method 56

$3.3 \quad$ Study Findings 57

3.3.1 Availability of devices, their usage and perception about 58 prices

3.3.2 Usage and perception about e-learning 61

3.3.3 Usage and perception about m-learning 62

3.4 Summary of Findings and Chapter Conclusion 66 


\section{CHAPTER FOUR: PROPOSED CONCEPTUAL MODEL AND RESEARCH HYPOTHESES}

4.1 Electronic Service Quality (E-SQ): Conceptual Foundations 68

4.1.1 E-SQ Definition and Dimensions 68

4.1.2 Conceptual Model of E-SQ 73

4.2 Notion of e-SQ Useful Concepts 77

4.2.1 Customer Expectations of Service Delivery: Nature and 77 Determinants

4.2.2 Online Customer Satisfaction as a Measure of E-SQ 79

4.2.3 The Relationships between Service Quality, Customer 80

Satisfaction, and Behavioral Intention

4.3 Website Quality Factors $\quad 82$

4.3.1 The Notion of Website Quality for a Consumer 82

4.3.1.1 Website E-Services Related to the Online 83 Shopping Process

4.3.1.2 Website E-Services Related to User Interface and 84 Web Design

4.3.1.3 Website Quality E-Services Related to Internet 86 Privacy/Security

4.4 Assessment and Measurement of Website E-SQ 89

4.4.1 Current Trends and Issues in the Area 86

4.4.2 Main Website E-SQ Assessment Techniques 89

4.4.2.1 E-SERVQUAL 90

4.4.2.2 WEBQUAL 92

4.4.2.3 eTailQ 94

4.4.2.4 Comparison of the Reviewed E-SQ Scales and 95 their Impact on Study

$\begin{array}{lll}4.5 & \text { User Satisfaction } & 98\end{array}$

4.5.1 User satisfaction and IS success 99

4.5.2 Satisfaction in the Context of IS Services 103

$\begin{array}{lll}4.6 & \text { IS Service Quality } & 104\end{array}$

4.7 Measuring Service Quality in Higher Education 106 
$\begin{array}{lll}4.8 & \text { Proposed Conceptual Research Model } & 110\end{array}$

4.8.1 Proposed Conceptual Research Model Dimensions 111

4.8.1.1 Service Quality Dimensions 114

4.8.1.2 Information Quality Dimensions 118

4.8.1.3 System Quality Dimensions 120

4.8.1.4 The Relationships between Service Quality, 123 Satisfaction, and Behavioral Intention

4.8.2 Hypotheses Formulation 124

4.8.3 Operationalization of the Research Variables 127

$\begin{array}{lll}4.9 & \text { Chapter Conclusion } & 130\end{array}$

\section{CHAPTER FIVE: RESEARCH DESIGN}

5.1 Purpose of Research

5.2 Research Approach

5.2.1 Causal vs. Correlation 134

5.2.2 Unit of Analysis 136

5.2.3 Deductive vs. Inductive 136

$\begin{array}{lll}5.3 & \text { Research Strategy } & 137\end{array}$

$\begin{array}{lll}5.4 & \text { Data Collection Methods } & 138\end{array}$

5.4.1 Online Survey vs. Offline (traditional) 138

$\begin{array}{ll}\text { 5.4.2 Using secondary data } & 139\end{array}$

$\begin{array}{lll}5.5 & \text { Probability vs. Non-Probability Sampling } & 140\end{array}$

$\begin{array}{lll}\text { 5.5.1 Probability Sampling } & 140\end{array}$

5.5.2 Stratified Random Sampling 141

5.6 Research Instrument Development 142

$\begin{array}{lll}\text { 5.6.1 Subjects } & 142\end{array}$

5.6.2 Sample Size and Response Rates 143

5.6.3 Potential Sample Bias 146

$\begin{array}{lll}\text { 5.6.4 Scale Development } & 147\end{array}$

$\begin{array}{lll}\text { 5.6.5 Procedure Overview } & 148\end{array}$ 
$\begin{array}{lll}\text { 5.6.7 Instrument Validation } & 149\end{array}$

$\begin{array}{lll}5.6 .8 & \text { Face Validity } & 150\end{array}$

$\begin{array}{ll}\text { 5.6.9 Content Validity } & 150\end{array}$

5.6.10 Threats to Validity 151

5.6.11 Pre-Test 152

5.6.12 Pilot test 152

$\begin{array}{ll}\text { 5.6.13 Final Instrument } & 156\end{array}$

$\begin{array}{ll}\text { 5.6.14 Survey administration } & 157\end{array}$

$\begin{array}{lll}5.7 & \text { Chapter Conclusion } & 157\end{array}$

\section{CHAPTER SIX: DATA ANALYSIS AND RESULTS}

$\begin{array}{lll}6.1 & \text { Data Analysis Strategy } & 159\end{array}$

$\begin{array}{lll}6.2 & \text { The Data } & 160\end{array}$

6.2.1 Data Inspection 160

$\begin{array}{ll}6.2 .2 \text { Visual Inspection } & 160\end{array}$

$\begin{array}{lll}\text { 6.2.3 Missing Data } & 160\end{array}$

6.2.4 Normality Assessment 161

6.3 Respondents' Profile 163

6.4 Exploratory Factor Analysis $\quad 166$

$\begin{array}{lll}6.5 & \text { Validity Testing } & 171\end{array}$

$\begin{array}{lll}\text { 6.5.1 Construct Validity } & 171\end{array}$

6.5.2 Convergent Validity 172

$\begin{array}{lll}\text { 6.5.3 Discriminant Validity } & 172\end{array}$

6.5.4 Statistical Conclusion Validity 173

$\begin{array}{lll}6.6 & \text { Research Model Evaluation } & 173\end{array}$

$\begin{array}{lll}\text { 6.6.1 Hypothesis Testing } & 174\end{array}$

$\begin{array}{lll}\text { 6.7 Answering the Research Questions } & 183\end{array}$

$\begin{array}{lll}6.8 & \text { Model Evaluation } & 189\end{array}$ 


\section{CHAPTER SEVEN: PROTOTYPING EVALUATION AND IMPLEMENTATION}

7.1 System Development Methodology 193

$\begin{array}{lll}7.2 & \text { Object Oriented Development } & 194\end{array}$

7.3 Unified Modeling Language (UML) 194

7.4 Rapid Application Development (RAD) 195

7.4.1 Analysis Phase 296

7.4.1.1 Service Technology Analysis 201

7.4.1.2 User Requirements 199

7.4.1.3 Interview Findings 199

7.4.1.4 The implications of the m-learning service quality 201 factors on the proposed MLSP

7.4.1.4.1 Interface Design 203

7.4.1.4.2 Reliability 204

7.4.1.4.3 Trust 204

7.4.1.4.4 Content Usefulness 205

7.4.1.4.5 Content Adequacy 205

7.4.1.4.6 Ease of use 206

7.4.1.4.7 Accessibility 207

7.4.1.4.8 Interactivity 207

7.4.2 Design Phase 208

$\begin{array}{ll}\text { 7.4.3 Construction phase } & 217\end{array}$

7.4.4 Implementation 218

$\begin{array}{lll}7.5 & \text { Prototype Evaluation } & 226\end{array}$

7.5.1 Evaluation Techniques 228

7.5.1.1 User Involvement 229

7.5.1.2 Conducting the Test 230

7.5.2 Analysis of Results 231 


\section{CHAPTER EIGHT: DISCUSSION OF FINDINGS AND CONCLUSION}

8.1 Summary 239

8.2 Research Achievements 240

8.2.1 Hypotheses 241

8.2.2 Research questions 241

8.2.3 Research objectives 253

8.3 Contributions 255

$\begin{array}{lll}8.4 & \text { Limitations } & 259\end{array}$

$\begin{array}{lll}8.5 & \text { Future research } & 260\end{array}$

$\begin{array}{lll}8.6 & \text { Conclusions } & 261\end{array}$

REFERENCES 264 


\section{LIST OF APPENDIXES}

Appendix A: Qualitative initial Mobile Learning Services survey results and descriptive statistics of respondents' characteristics

Appendix B: Measurement Scales and Reliabilities of M-learning Service Quality

Appendix C: Quantitative Descriptive Statistics

Appendix D: A Questionnaire Survey on Mobile Learning Service Quality

Appendix E: Quantitative Frequency Distribution

Appendix F: Factor Analysis Procedure

Appendix G: Various Diagrams Used in UML

Appendix H: Computer System Usability Questionnaire (CSUQ)

Appendix I: Tasks Sheet 


\section{LIST OF TABLES}

2.1 Mobile Wireless Technologies Uses in Higher Education 28

$3.1 \quad$ M-learning services initial survey results $\quad 52$

3.2 Students' preferences for mobile services 59

4.1 Outline of the Main Research on SQ and E-SQ 83

5.1 Differences between Qualitative and Quantitative Data 127

5.2 Relevant Situations for Different Research Strategies 131

$\begin{array}{lll}5.3 & \text { One-Sample Test } & 139\end{array}$

$\begin{array}{lll}5.4 & \text { Independent Samples Test } & 140\end{array}$

$\begin{array}{lll}5.5 & \text { Testing Alpha Item-Total Statistics } & 148\end{array}$

5.6 Testing Alpha Item-Total Statistics 149

$\begin{array}{lll}6.1 & \text { Outliers list } & 157\end{array}$

6.2 Respondents Profile Summary 159

6.3 Items Dropped During Exploratory Factor Analysis 162

$\begin{array}{lll}6.4 & \text { Exploratory Factor Loadings } & 164\end{array}$

$\begin{array}{lll}6.5 & \text { Hypothesis }(\mathrm{H} 1) \text { Correlations } & 171\end{array}$

$\begin{array}{lll}6.6 & \text { Hypothesis }(\mathrm{H} 2) \text { Correlations } & 171\end{array}$

$\begin{array}{lll}6.7 & \text { Hypothesis (H4) Correlations } & 172\end{array}$

$\begin{array}{lll}6.8 & \text { Hypothesis (H5) Correlations } & 172\end{array}$

6.9 Hypothesis (H6) Correlations 173

$\begin{array}{lll}6.10 & \text { Hypothesis }(\mathrm{H} 7) \text { Correlations } & 173\end{array}$

$\begin{array}{lll}6.11 & \text { Hypothesis (H8) Correlations } & 174\end{array}$

$\begin{array}{lll}6.12 & \text { Hypothesis (H9) Correlations } & 174\end{array}$

$\begin{array}{lll}6.13 & \text { Hypothesis (H10) Correlations } & 175\end{array}$

6.14 Hypothesis (H11) Correlations 175

$\begin{array}{lll}6.15 & \text { Hypothesis (H12) Correlations } & 176\end{array}$

6.16 Hypothesis Testing Results 177

6.17 Correlations Matrix between Overall Service Quality and Nine 182 M-learning Service Quality Dimensions 
6.18 Regression Analysis Results between Overall Service Quality and M-learning Service Quality Dimensions

6.19 Correlations Matrix between Overall Service Quality and Learner Satisfaction

6.20 Regression Analysis Results between Learner Satisfaction and Overall Service Quality Dimension

6.21 Correlations Matrix between Learner Satisfaction and Behavioral Intention

6.22 Regression Analysis Results between Behavioral Intention and Learner Satisfaction Dimension

6.23 Parameter Estimates and Determination Coefficients for Hypothesized and Rival Model

7.1 Analogies between Sun ONE and Microsoft.NET

7.2 Participants' characteristics

7.3 Participants' characteristics

7.4 Benchmark Task Completion Times

7.5 Performance Score Summaries and Mean Time $(\mathrm{N}=10) \quad 216$

$\begin{array}{lll}7.6 & \text { System Usefulness }(\mathrm{N}=10) & 218\end{array}$

$\begin{array}{lll}7.7 & \text { Information Quality }(\mathrm{N}=10) & 219\end{array}$

$\begin{array}{lll}7.8 & \text { Interface Quality }(\mathrm{N}=10) & 220\end{array}$

$\begin{array}{lll}7.9 & \text { Overall Satisfaction }(\mathrm{N}=10) & 220\end{array}$ 


\section{LIST OF FIGURES}

2.1 Wired virtual learning environment 16

$\begin{array}{lll}2.2 & \text { Wireless learning environment } & 18\end{array}$

2.3 The subsets of flexible learning 19

2.4 Mobile Learning Components 20

$\begin{array}{lll}2.5 & \text { Traditional Method of Learning } & 21\end{array}$

$\begin{array}{lll}2.6 & \text { M-Learning Environment } 21\end{array}$

2.7 Gronroos (1984)'s Service Quality Model 46

$\begin{array}{lll}2.8 & \text { Drivers of customer satisfaction } & 47\end{array}$

3.1 Students' availability of devices 53

3.2 Students' opinion about devices prices 54

3.3 Students' opinion about services prices 55

3.4 Students' utilizing of an m-learning system 57

3.5 Students' Perception on the usage of m-learning and the quality of 58

3.6 Students' preferences for mobile services 60

3.7 Students' view of an m-learning system 60

4.1 Conceptual model for understanding and improving e-SQ $\quad 69$

4.2 Nature and Determinants of Service Expectations by Customers $\quad 73$

$\begin{array}{lll}4.3 & \text { IS Success Model }\end{array}$

4.4 Updated DeLone and McLean IS Success Model 94

4.5 Proposed conceptual research model dimensions 106

$\begin{array}{lll}4.6 & \text { Hypotheses Research Model } & 118\end{array}$

4.7 Operationalization of M-learning Services Quality Variables 122

6.1 Research Model with Correlation Coefficients and Squared 179

6.2 Rival Model with Correlation Coefficients and Squared 187

$\begin{array}{lll}7.1 & \text { Rapid Application Development Route }\end{array}$

$\begin{array}{lll}7.2 & \text { The MLSP Infrastructure } & 198\end{array}$

7.3 MLSP UML Use Case Diagram 200

$\begin{array}{lll}7.4 & \text { Login Sequence Diagram } & 201\end{array}$ 
$\begin{array}{lll}7.5 & \text { Courses Sequence Diagram } & 202\end{array}$

7.6 Search Sequence Diagram 203

7.7 My Profile Sequence Diagram 204

7.8 FAQs Sequence Diagram 205

$\begin{array}{lll}7.9 & \text { Contact Us Sequence Diagram } & 206\end{array}$

\begin{tabular}{ll}
7.10 & Navigation map of MLSP \\
\hline
\end{tabular}

7.11 Login Interface 208

$\begin{array}{lll}7.12 & \text { Main Menu Interface } & 208\end{array}$

$\begin{array}{lll}7.13 & \text { Courses List } & 209\end{array}$

$\begin{array}{lll}7.14 & \text { Course Details } & 209\end{array}$

$\begin{array}{lll}7.15 & \text { Announcements List } & 210\end{array}$

$\begin{array}{ll}7.16 & \text { Announcement Description } \\ & 210\end{array}$

8.1 Hypotheses Research Model 226 


\section{LIST OF ABBREVIATION}

\begin{tabular}{ll} 
ICT & Information And Communication Technology \\
MLSP & Mobile Learning System Prototype \\
WAP & Wireless Application Protocol \\
UMTS & Universal Mobile Telecommunications System \\
PDA & Personal Digital Assistant \\
SMS & Short Message Service \\
MMS & Multimedia Message Service \\
WNIC & Wireless Network Interface Card \\
PC & Personal Computer \\
SQ & Service Quality \\
SERVQUAL & Service Quality Model \\
E-SQ & Electronic Service Quality \\
IS & Information Systems \\
SEM & Structural Equation Matrix \\
EFA & Exploratory Factor Analysis \\
PCA & Principal Components Analysis \\
MSA & Measure Of Sampling Adequacy \\
KMO & Kaiser-Meyer-Olkin \\
RAD & Rapid Application Development \\
OO & Object-Oriented \\
UML & Unified Modeling Language \\
COM & Common Object Model \\
CLR & Common Language Runtime \\
JVM & Java Virtual Machine \\
FAQs & Frequently Asked Questions \\
WiFi & Wireless Fidelity \\
GPRS & General Packet Radio Service \\
\hline
\end{tabular}


HCI Human Computer Interaction

ISO International Standard Organization

CSUQ Computer System Usability Questionnaire 


\section{Chapter One}

\section{INTRODUCTION}

In this chapter, the researcher will discuss some background information about mobile learning service and service quality. This will be followed by statement of the problem, research questions, research objective and significance of the research.

\subsection{Introduction}

The walls of the classrooms have been torn down, as computer technology evolution has widened the educational activities for instructors and students in the 90's. The Internet technology has removed time and space constraints from instructors as well as students. With the rapid diffusion of the Internet, computers, and telecommunications new approaches to learning were created (Berge \& Collins, 1995; Crosta, 2004). On-line courses appeared as a new method of course delivery, since then, the interest in the development and use of distance learning in higher education has been steadily increasing (Dabbagh \& Kitsantas, 2003).

This rapid diffusion of the Internet and its deployment in learning, as well as on-line courses delivery is represented by Electronic Learning (e-learning). The demands of e-learning in connection with the possibilities offered by modern technology (evolution of mobile devices), pose new opportunities and new

challenges to the educational systems. Tools and devices immerse in the learning environment and surround educators, students and the environment in which they 


$$
\begin{aligned}
& \text { The contents of } \\
& \text { the thesis is for } \\
& \text { internal user } \\
& \text { only }
\end{aligned}
$$


Finally, the tunnel vision seems to inhibit people's ability to "think outside the box". Many, especially those with packaged software, do not seem to be able to envision alternatives to accomplish m-learning service objectives other than with packaged software. Therefore, it appears nearly certain and plausible that the way mlearning service quality is implemented in the future will also change. This will require us to re-think what m-learning service quality "is" in the future before we have completely determined what m-learning service quality "is" now. 


\section{REFERENCE}

Aaker, D. A., \& Day, G. S. (1990). Marketing Research (4th ed.): New York: John Wiley \& Sons, Inc.

Abdul Karim, N. S., Darus, S. H., \& Hussin, R. (2006). Mobile phone applications in academic library services:a students' feedback survey. Campus-Wide Information Systems, 23(1), 35-51.

Ahituv, N. (1980). A systematic approach toward assessing the value of an information system. MIS Quarterly, 4(4), 61-75.

Aladwani, A. M., \& Palvia, P. C. (2002). Developing and validating and instrument for measuring user-perceived Web quality. Information \& Management, 39(6), 467-476.

Aldridge, S., \& Rowley, R. (1998). Measuring customer satisfaction in higher education. Quality Assurance in Education, 6(4), 197-204.

Allen, J., \& Davise, D. (1988). Searching for excellence in marketing education: The relationshipe between service quality and three outcome variables. Journa of Marketing Education, Spring, 44-55.

Alter, S. L. (1992). Information Systems: A Management Perspective (2 ed.): Addison-Wesley, Reading, MA.

Anderson, C. (1997). Enabling and shaping understanding through tutorials. The experience of learning 184-197.

Anderson, E. W., \& Sullivan, M. W. (1993). The antecedents and consequences of customer satisfaction for firms. Marketing Science, 12(2), 125-143.

Anderson, E. W., Fornell, C., \& Lehmann, D. R. (1994). Customer satisfaction,market share, and profitability: Findings from Sweden. Journal of Marketing 58, 53-66.

Anderson, R. E. (1973). Consumer dissatisfaction: The effects of disconfirmed expectancy on perceived product performance. Journal of Marketing Research, $10,38-44$.

Asubonteng, P., McCleary, K. J., \& Swan, J. E. (1996). SERVQUAL revisited: A critical review of service quality. Journal of Services Marketing, 10(6), 62-81.

Attewell, J., \& Savill-Smith, C. (2003). Mobile Learning and Social Inclusion: Focusing on Learners and Learning [Electronic Version]. Retrieved December 25, 2005 from http://www.lsda.org.uk/files/pdf/1440.pdf. 
Attewell, J. (2005). Mobile technologies and learning. Learning and Skills Development Agency, United Kingdom.

Babakus, E., \& Boiler, G. W. (1992). An empirical assessment of the SERVQUAL scale. Journal of Business Research, 24, 253-268.

Bailey, J. E., \& Pearson, S. W. (1983). Development of a Tool for Measuring and Analyzing Computer User Satisfaction. Management Science, 29(5), 530 -545 .

Bandyo-padhyay, N. (2002). E-commerce: Context, Concepts and Consequences. UK: McGraw-Hill International.

Barnes, S. J., \& Vidgen, R. (2001). An evaluation of cyber-bookshops the WebQual method. International Journal of Electronic Commerce, 6(1), 11-30.

Bartel, C., \& Meerts, J. (2002). Overview of next generation wireless data [Electronic Version]. Retrieved January 6, 2006 from http://www.educause.edu/ir/library/pdf/DEC0204.pdf.

Belcher, M., Place, E., \& Conole, G. (2000). Quality assurance in subject gateways: creating high quality portals on the internet. Quality Assurance in Education $8(1), 38-47$.

Bennett, S., McRobb, S., \& Farmer, R. (2000). Object Oriented System Analysis and Design using VML: McGraw-Hill: London.

Berge, L. Z., \& Collins, M. P. (1995). Computer mediated communication and the online classroom. Distance learning, Volume III. Cresskill, NJ: Hampton Press.

Berger, C. (2001). Wireless: Changing Teaching and Learning "Everywhere, Everytime”. EDUCASE review, 51-59.

Berry, L. L., A. Parasuraman, \& Zeithaml, A. V. (1994). Improving Service Quality in America: Lessons Learned. Academy of Management Executive, 8(2), 32-52.

Berry, L. L., Zeitham1, V. A., \& Parasuraman, A. (1985). Quality counts in services, too. Business Horizons, 28(3), 44-52.

Bhattacherjee, A. (2001). An Empirical Analysis of the Antecedents of Electronic Commerce Service Continuance. Decision Support Systems, 32(2), 201-214.

Bishop, A. L., Dinkins, R. K., \& Dominick, J. L. (2003). Programming handheld devices to enhance learning. Journal Educause Quarterly, 1, 50-53.

Bitner, M. J. (1990). Evaluating service encounters: The effects of physical surroundings and employee responses. Journal of Marketing Research, 54, 69-82. 
Bitner, M. J., Brown, S. W., \& Meuter, M. L. (2000). Technology infusion in service encounters Journal of the Academy of Marketing Science 8(1), 138-149.

Bitner, M. J., \& Hubbert, A. R. (1994). Service Quality: New directions in theory and practice: Thousand Oaks, CA: Sage Publications.

Bleuel, W. (2004). Customer Satisfaction Series: Customer Satisfaction. Part 1. In: Scantron corp. Survey services Retrieved January 6, 2007, from http://www.scantron.com/services/survey/article cs_pl.asp.

Bloemer, J., \& Kasper, H. (1995). The complex relationship between consumer satisfaction and brand loyalty. Journal of Economic Psychology, 16(1), 311-329.

Bloemer, J., \& Ruyter, K. (1998). Integrating Service Quality and Satisfaction: Pain in the Neck or Marketing Opportunity? Journal of Consumer Satisfaction Dissatisfaction and Complaining Behavior, 8(1), 44-52.

Boggs, R. (2002). ECAR study: Trends in wireless communications in higher education seminar on academic computing [Electronic Version]. Retrieved January 6, 2006 from https://www.educause.edu/ir/library/pdf/EDU0218.pdf.

Bolton, R. N., \& Drew, J. (1991). A Longitudinal Analysis of the Impact of Service Changes on Customer Attitudes. Journal of Marketing, 55 (January), 1-9.

Boulding, W., Kalra, A., Staelin, R., \& Zeithaml, V. A. (1993). A Dynamic Process Model of Service Quality: From Expectations to Behavioural Intentions. Journal of Marketing Research, 30(February), 7-27.

Boulding, W., Staelin, R., Kaira, A., \& Zeithaml, A. (1993). A dynamic process model of service quality: From expectations to behavior intentions. Journal of Marketing Research, 3(2), 7-27.

Bouman, M., \& van der Wiele, T. (1992). Measuring service quality in the car service industry: Building and testing an instrument. International Journal of Marketing Research, 30, 7-27.

Bowers, M. R., Swan, J. E., \& Koehler, W. F. (1994). What attributes determine quality and satisfaction with health care delivery. Health Care Management Review, 19(4), 49-55.

Boynton, A. C., \& Zmud, R. W. (1988). Information planning in the 1990's: Directions for practice and research. MIS Quarterly, 11(1), 59-71.

Brady, K., \& Robertson, J. (2001). Searching for a Consensus on the Antecedent Role of Service Quality and Satisfaction: An Exploratory Cross-National Study. Journal of Business Research, 51(1), 53-60.

Brown, J., Collins, A. \& Duguid, P. (1989). Situated cognition and the culture of learning. Educational Researcher, 18(1), 32-42. 
Brown, J., Churchill, A., \& Peter, J. (1993). Improving the Measurement of Service Quality. Journal of Retailing, 69(1), 127-139.

Brown, S. W., \& Swartz, TA. (1989b). Consumer and provider expectations and experiences in evaluating professional service quality. Marketing Science, 7(1), 70-82.

Brown, T. (2003). The role of m-learning in the future of e-learning in Africa. Paper presented at the 21 st ICDE World Conference.

Brown, T. (2004a). Towards a model for m-learning in Africa. Retrieved December 25, 2005, from http://www.up.ac.za/telematic/article.pdf.

Brown, T. (2004b). The role of m-learning in the future of e-learning in Africa. Paper presented at the Distance Education and Technology: Issues and Practice, Open University of Hong Kong Press, Hong Kong, China.

Buhalis, D. (1999). Information Technology for Small and Medium-Sized Tourism Enterprises: Adaptation and Benefits. Information Technology \& Tourism, 2(2), 79-95.

Buttle, F. (1996). SERVQUAL: Review, critique, research agenda. European Journal of Marketing, 30(1), 8-32.

Buzzel, R. D., \& Gale, B. T. (1987). The PIMSprinciples: Linking strategy to performance: New York, NY: Free Press.

Cadotte, E. R., Woodruff, R. B., \& Jenkins, R. L. (1987). Expectations and norms in models of consumer satisfaction. Journal of Marketing Research, 24, 305-314.

Campbell, D. T., \& Fiske, D. W. (1959). Convergent and discriminant validation by the multitrait-multimethod matrix. Psychologocal Bulletin, 5(6), 81-105.

Carman, J. M. (1990). Consumer perceptions of service quality: An assessment of the SERVQUAL dimensions. Journal of Retailing, 66(1), 33-55.

Caruana, A. t., Ewing T., \& Ramaseshan, B. (2000). Assessment of the Three-Column Format SERVQUAL: An Experimental Approach. Journal of Business Research, 49(1), 57-65.

Cash, J. L., McFarlan, F. W., \& McKenney, J. L. (1992). Corporate Information Systems Management: The Issues Facing Senior Executives (3 ed.): Irwin, Homewood, IL.

Chabra, T., \& Figueiredo, J. (2002). How To Design and Deploy Handheld Learning. Retrieved December 25, 2005, from http://www.empoweringtechnologies.net/eLearning/eLearning_expov5 files/ frame.htm. 
Chen, Q., \& Wells, D. W. (1999). Attitude toward the Site. Journal of Advertising Research, 39(5), 27-37.

Chen, Y. (2002). The merits / Defects of Distance Education for Curriculum, Teachers, and Students. Retrieved December 25, 2005, from http://www.mste.uiuc.edu/courses/ci499sp01/students/ychen17/pages/dlearni ng.html.

Chen, Y., Kao, T., Yu, G., \& Sheu, J. (2004). A Mobile Butterfly-Watching Learning System for Supporting Independent Learning. Paper presented at the The 2nd IEEE International Workshop on Wireless and Mobile Technologies in Education (WMTE'04).

Chiu, C., Hsu, M., Sun, S., Lin , T., \& Sun, P. (2004). Usability, quality, value and e-learning continuance decisions. Computer and Education, 5(2).

Cho, N., \& Park, S. (2001). Development of electronic commerce user-consumer satisfaction index (ECUSI) for Internet shopping. Industrial Management \& Data Systems, 707(8), 400-405.

Chung, T., \& Law, R. (2003). Developing a Performance Indicator for Hotel Websites. Hospitality Management, 22, 119-125.

Cisco System. (2003). Louisiana State University implements Cisco CTE 1400 series content transformation engines. Retrieved January 6, 2006, from http://www.cisco.com/warp/public/cc/pd/witc/ctel400/prodlit/louisbc.htm.

Clark, L. A., \& Watson, D. (1995). Constructing Validity: Basic Issues in Objective Scale Development Psychological Assessment, 7(3), 309-319.

Coakes, S. j., \& Steed, L. G. (2003). SPSS analysis without anguish: John Wiley \& Sons, Sydney: Australia.

Cohen, J., Fishbein, M., \& Ahtola, O. (1972). The Nature and Uses of Expectancy Value Models in Consumer Attitude Research. Journal of Marketing Research, 9(November), 456-460.

Cole, G. (2001). The classless society Connectics. Retrieved November 15, 2005, from http://specials.ft.com/connectis/june2001/FT3EFBND7OC.html

Compeau D .R., \& A., H. C. (1995). Computer self-efficacy: Development of a measure and initial test. MIS Quarterly, 18(3), 189-211.

Cöner, A., \& Güngör, M. (2002). Factors affecting customer loyalty in the competitive Turkish metropolitan retail markets. Journal of American Academy of Business, 2(1), 189-195.

Cook, T. D., \& Campbell, D. T. (1979). Quasi-experimentation: Design \& Analysis Issues for Field Settings (1 ed.): DT Campbell, Rand McNally \& Co, US. 
Corlett, D., \& Sharples, M. (2004). Tablet Technology of Information Collaboration in Higher Education. Paper presented at the MLearn 2004.

Costabile, M. F., De Marsico, M., Lanzilotti, R., Plantamura, V. L., \& Roselli, T. (2005). On the Usability Evaluation of E-Learning Applications. Paper presented at the 38th Hawaii International Conference on System Sciences, Hawaii.

Cox, R., \& Dale, B. G. (2001). Service quality and e-commerce: An exploratory analysis. Managing Service Quality, 77(2), 121-131.

Cramer, D. (1998). Fundamental statistics for social research: Routledge, London:UK.

Crawford, V., \& Vahey, P. (2001). Palm education pioneers program: Round I preliminary evaluation report: SRI International [Electronic Version]. $\begin{array}{llll}\text { Retrieved November } & 15, & 2005 & \text { from }\end{array}$ http://www.palmgrants.sri.eom/PEPR1Report.pdf.

Crompton, J. L., \& MacKay, K. J. (1989). Users' perceptions of the relative importance of service quality dimensions in selected public recreation programs. Leisure Sciences, 11, 367-375.

Cronin, J. J., \& Taylor, S. A. (1992). Measuring service quality: A reexamination and extension. Journal of Marketing Research, 56(3), 55-68.

Cronin, J. J., \& Taylor, S. A. (1994). Servperf Versus Servqual: Reconciling performance-Based And Perceptions-Minus-Expectations Measurement Of Service Quality. Journal Of Marketing, 58(3), 125-131.

Crosta, L. (2004). Beyond the use of new technologies in adult distance courses: an ethical approach. International Journal on E-Learning, 3(1), 48-61.

Dabbagh, N., \& Kitsantas, A. (2003). Supporting self-regulation in student-centered web-based learning environments. International Journal on E-Learning, 3(1), 40-48.

Dabholkar, A., Shepherd, C., \& Thorpe, I. (2000). A Comprehensive Framework for Service Quality: An Investigation of Critical Conceptual and Measurement Issues Through a Longitudinal Study. Journal of Retailing, 76(2), 139-173.

Dabholkar, P. A. (1996). Consumer Evaluations of New Technology based Self-Service Options: An Investigation of Alternative Models of SO. International Journal of Research in Marketing, 13(I), 29-51.

Dabholkar, P. A. (1996). Consumer evaluations of new technology-based self-service options: An investigation of alternative models of service quality. International Journal of Research in Marketing, 13, 29-51. 
Daffy, C. (2001). Customer experience management. European Quality, 8(4), 50-55.

Davidson, A. R., Chelson, J.V., \& Janes, F.R. (2001). An New Tool for Assessing the Presence of Total Quality. The TQM Magazine, 13(1), 12-24.

Davis, D., Bagozzi, Richard P., \& Warshaw R. (1989). User Acceptance of Computer Technology: A Comparison of Two Theoretical Models Management Science, 35(8), 982-1003.

Davis, F. D. (1989). Perceived Usefulness, Perceived Ease of Use, and User Acceptance of Information Technology. MIS Quarterly, 13(3), 319-339.

Davis, F. D., Bagozzi, R. P., \& Warshaw, P. R. (1992). Extrinsic and intrinsic motivation to use computers in the workplace. Journal of Applied Social Psychology, 22(14), 1109-1130.

Dearden, J. (1987). The withering of the MIS organization. Sloan Management Review, 28(4), 87-91.

Dedeke, A. (2003). Service quality: a fulfillment-oriented and interaction-centred approach. Managing Service Quality, 13(4), 276-289.

Dellaert, B. G., \& Kahn, B. E. (1999). How tolerable is delay?: Consumers' evaluations of Internet web sites after waiting. Journal of Interactive Marketing, 75(1), 41-54.

DeLone, W. H., \& McLean, E. R. (1992). Information Systems Success: The Quest for the Dependent Variable. Information Systems Research, 3(1), 60 -95.

DeLone, W. H., \& McLean, E. R. (2003). The DeLone and McLean Model of Information Systems Success: A ten-year update. Journal of Management Information Systems, 19(4), 9-30.

Devlin, F., Gwynne, L., \& Ennew, T. (2002). The Antecedents of Service Expectations. The Service Industries Journal, 22(4), 117-136.

Doherty, N. F., Ellis-Chadwick, F., \& Hart, C. A. (1999). Cyber retailing in the UK: The potential of the Internet as a retail channel. nternational Journal of Retail and Distribution Management, 27(1), 22-36.

Doll, W. J., \& Ahmed, M. V. (1985). Documenting information systems for management: A key to maintaining user satisfaction Information and Management, 8(4), 221-226.

Doll, W. J., \& Torkzadeh, G. (1988). The measurement of end-user computing satisfaction. MIS Quarterly, 12(2), 259-274.

Doll, W. J., \& Torkzadeh, G. (1991). The measurement of end-user computing satisfaction:Theoretical and methodological issues. MIS Quarterly, March, 5-10. 
Ducoffe, R. H. (1996). Advertising value and advertising on the web. Journal of Advertising Research, 3(6), 21-35.

Dye, A. (2003). Mobile Education - A Glance at The Future. Retrieved December 25,2005, from http://www.dye.no/articles/a glance at the future/index.html.

Ebbelink, I. (2005). Computer-Mediated Communication [Electronic Version]. Retrieved December 25, 2005 from http://gasa.dcea.fct.unl.pt/julia/ensino/ inki.html.

Ein-Dor, P., \& Segev, E. (1978). Organizational context and the success of management information systems. Management Science, 24(10), 1064-1077.

Emery, J. C. (1971). Cost/benefit analysis of information systems (No. 1). Chicago, IL: The Society for Management Information Systems.

Engestrom, Y. (1994). Training For Change: New Approach to Instruction and Learning in Working Life. International Labour Office, Geneva.

Falk, J. H., \& Dierking, L. D. (2002). Lessons without Limits: how free choice learning is transforming education. Institute for Learning Innovation.

Fernandez, B., \& Fernandez, H. (2004). Comparing the security architectures of Sun One and Microsoft.Net. Department of computer Science and Engineering, Florida Atlantic University.

Finn, D. W., \& Lamb, C. W. (1991). An evaluation of the SERVQUAL scales in a retailing setting. Advances in Consumer Research, 18, 483-490.

Fisk, R. B., Bitner, M., \& Young, C. E. (1993). Tracking the evolution of the services marketing literature. Journal of Retailing, 69(1), 61-103.

Fiske, S., \& Neuberg, S. (1990). A Continuum of Impression Formation from Category-Based To Individuating Processes: Influences of Information and Motivation on Attention and Interpretation. Advances in Experimental Social Psychology, 23, 1-74.

Fryer, W. A. (2002). Wireless computing: New opportunities and challenges in education. Retrieved January 6, 2006, from http://www.wtvi.com/teks/02_03_articles/wirelessfuture.html

Galbus, A. C. (2001). Are wireless computers a cost effective alternative to fixed documenting and reviewing patient cares?, Cardinal Stritch University.

Gallagher, C. A. (1974). Perceptions of the value of a management information system. Academy of Management Journal, 17(1), 46 - 55.

Gardial, S. F., Clemons, D., Woodruff, D. W., Schumann, D. W., \& Burns, M. J. (1994). Comparing Consumers' Recall of Prepurchase and Postpurchase Product Evaluations Experiences. Journal of Consumer Research, 20(March), 
$548-560$.

Garner, I., Francis, J., \& Wales, K. (2002). An evaluation of the implementation of a short messaging system (SMS) to support undergraduate student learning. Paper presented at the European Workshop on Mobile and Contextual Learning, Birmingham, UK.

Gefen, D. (2002). Customer loyalty in e-commerce. Journal of the Association for information Systems, 13, 27-51.

Gelderman, M. (1998). The relation between user satisfaction, usage of information systems and performance. Information \& Management, 34, 11 - 18.

Georgieva, E., Smrikarov, A., \& Georgiev, T. (2005). A General Classification of Mobile Learning Systems. Paper presented at the International Conference on Computer Systems and Technologies - CompSysTech' 2005.

Ghobadian, A., Speller, S., \& Jones, M. (1994). Service quality concepts and models. International Journal of Quality \& Reliability Management, 77(9), 43-66.

Ghose, S., \& Dou, W. (1998). Interactive functions and their impacts on the appeal of Internet presence sites. Journal of Advertising Research, 38(2), 29-43.

Gitte, L. (1994). Usability testing and system evaluation (1 ed.): Chapman \& Hall, London.

Goodhue, D. L., \& Thompson, R. L. (1995). Task-technology fit and individual performance. MIS Quarterly, 19(2), 213-236.

Gotlieb, J. B., Grewal, D., \& Brown, S. W. (1994). Consumer satisfaction and perceived quality: Complementary or divergent constructs? Journal of Applied Psychology, 79(6), 875-885.

Gounaris, S., \& Dimitriadis, S. (2003). Assessing Service Quality on the Web: Evidence from Business-to-Consumer Portals. Journal of Services Marketing, 17(5), 529-548.

Gounaris, S., \& Dimitriadis, S. (2003). Assessing Service Quality on the Web: Evidence from Business-to-Consumer Portals. Journal of Services Marketing, 17(5), 529-548.

Grohmann, G., Hofer, A., \& Martin, G. (2005). ARIS MOBILE Helping to define the future of mobile learning. Paper presented at the International Conference on Mobile Business (ICMB'05) 2005 IEEE.

Gronroos, C. (1982). An Applied Service Marketing Theory. European Journal of Marketing, 16(7), 30-41. 
Gronroos, C. (1984). A service quality model and its marketing implications. European Journal of Marketing, 18, 36-44.

Gronroos, C. (1990). Service Management and Marketing: Managing the Moments of Truth in Service Competition (2 ed.): Lexington, M.A.: Lexington Books.

Gronroos, C. (1998). Marketing Services: the Case of a Missing Product. Journal of Business \& Industrial Marketing, 13(4/5), 322-338.

Gronroos, C. (2001a). The Perceived Service Quality Concept - a Mistake? . Managing Service Quality, 11(3), 150-152.

Gronroos, C. (2001b). Service Management and Marketing: A Customer Relationship Marketing Approach (2 ed.). New York, NY: Wiley.

GSM-World. (2004). The World Wide Web Site of The GSM Association, (2004) GSM Facts and Figures [Electronic Version]. Retrieved December 15, 2005 from http://www.gsmworld/news/statistics/pdf/gsma stats_q2_04.pdf.

Guba, E., \& Lincoln Y. (1989). Fourth Generation Evaluation (1 ed.): Newbury park Sage Publications.

Gummerus, J., Liljander, V., Pura, M., \& van Riel, A. (2004). Customer loyalty to content-based web sties: the case of an online health-care service. Journal of Services Marketing, 18(3), 175-186.

Gummesson, E. (1990). Service Design. The Total Quality Management Magazine, 2(2), 97-101.

Gursoy, D. (2003). Prior Product Knowledge and Its Influence on the Travellers' Search Behaviour. Journal of Hospitality \& Leisure Marketing, 10(3/4), 113-131.

Guthrie, A. (1974). Attitudes of user-managers towards MIS. Management Informatics, 3(5).

Haga, W. J., \& Zviram, M. (1994). Information systems effectiveness: Research designs for causal inference. Journal of Information Systems, 4, 141 - 166.

Hair, J. F., Anderson, R. E., Tatham, R. L., \& Black, W. C. (1998). Multivariate data analysis: Upper Saddle River, NJ, Prentice Hall.

Hallowell, R. (1996). The Relationships of Customer Satisfaction, Customer Loyalty and Profitability: An Empirical Study. International Journal of Service Industry Management, 7(4), 27-42.

Hamilton, S., \& Chervany, N. L. (1981). Evaluating information system effectiveness. Part I. Comparing evaluation approaches. MIS Quarterly, 5(3), 55-69.

Hampton, G. M. (1993). Gap analysis of college student satisfaction as a measure of professional service quality. Journal of Professional Services Marketing, 9(1), 
115-128.

Harris, P. (2001). Going Mobile. Retrieved December 25, 2005, from http://www.learningcircuits.org/2001/jul2001/harris.html

Henke, H. (2005). Evaluating Web-based Instruction Design [Electronic Version]. Retrieved December 25, 2005 from http://scis.nova.edu/ henkeh/storyl.htm.

Hentea, M., Shea, M. J., \& Pennington, L. (2003). Distance education: A perspective on fulfilling the expectations of distance education Paper presented at the 4th conference on Information technology curriculum CITC4 103, Lafayette, Indiana, USA.

Hoffer, J. A., George, J. F., \& Valacich, J. S. (2002). Modern System Analysis \& Design (3 ed.): Upper Saddle River, New Hersey: Prentice Hall.

Hoffman, D., Novak, T., \& Peralta, M. (1999). Building consumer trust online. Communications of the ACM, 42(4), 80-85.

Hoffman, L., \& Novak, P. (1997). A New Marketing Paradigm for Electronic Commerce. The Information Society, special issue on electronic commerce, 13(5), 43-54.

Horstmanshof, L. (2004). Using SMS as a way of providing connection and community for first year students. Paper presented at the the 21st ASCILITE Conference Perth.

Houser, C., Thornton, P., Yokoi, S., \& Yasuda, T. (2001). Learning on the move: Vocabulary study via mobile phone email. Paper presented at the Enhancement of quality learning through information and communication technology, ICCE2001.

Huang, E. Y., \& Lin, C. Y. (2005). Customer-oriented financial service personalization. Industrial Management \& Data Systems, 105(1), 26-44.

Huang, M.-H. (2004). Web Performance Scale. Information \& Management. 14(10), 800-811.

Igersheim, R. H. (1976). Managerial response to an information system," AFIPS Conference Proceedings.

Inagaki, T., Kobayashi, Y., \& Nakagawa, H. (2004). Attitude Survey for pupils about Using Cellular Phones in Classrooms. Paper presented at the Ed-Media'04, Montreal, Canada.

ISO DIS 9241-11. (1998). Ergonomic Requirements for Office Work with Visual Display Terminal: Part 11: Guidance on specifying and measuring usability. International Organization for Standardization. 
Ives, B., Olson, M., \& Baroudi, S. (1983). The measurement of user information satisfaction. Communications of the ACM, 26(10), 785-793.

James, D. (2003). Learning Goes Mobile. Retrieved January 6, 2006, from http://www.thefeature.com/print?articleid=35283

Jay, C. (2004). E-Services: Satisfying customers online. Retrieved may 26, 2007 from http://www.buzzle.com/editorials/3-25-2004-52145.asp

Jensen, J. B., \& Markland, R. E. (1996). Improving the application of quality conformance tools in service firms. Journal of Service Marketing, 10(1), $35-55$.

Jiang, J. J., Klein, G. and Krampton, S. (2000). A note on SERVQUAL reliability and validity in information system service quality measurement. Decision Sciences, $31(1), 725-744$.

Jiang, J. J., Klein, G., \& Carr, C. L. (2002). Measuring information system service quality: SERVQUAL from the other side. MIS Quarterly, 26(2), 145-166.

Jianxin, J., Qinhai, M., \& Mitchell, M. (2003). Towards high value-added products and services: mass customization and beyond. Technovation, 23(10), 809-821.

Johnson, L. L., Dotson, M. J., \& Dunlap, B. J. (1988). Service quality determinants and effectiveness in the real estate brokerage industry. Journal of Real Estate Research, 3, 21-36.

Jones, C., Connolly, M., Gear, A., \& Read, M. (2002). Group interactive learning with group process support technology. British Journal of Education Technology, 32(5), 571-586.

Jun, M., \& Cai, S. (2001). The key determinants of Internet banking service quality: A content analysis. InternationalJournal of Bank Marketing, 19(1), 276-291.

Jun, M., Yang Z., \& D., K. (2004). Customers' perceptions of online retailing service quality and their satisfaction. International Journal of Quality \& Reliability Management, 2(8), 817-840.

Kavakl, H. (2004). A Course-Content Management System Development and its Usability. Middle East Technical University, Chemistry.

Kaynama, S. A., \& Black, C. I. (2002). A proposal to assess the service quality of online travel agencies: an exploratory study. Journal of Professional Services Marketing, 2(1), 63-88.

Kearney, G. W., \& Kearney, T. J. (1994). Transfer student expectations and satisfaction: Predictors for academic performance and persistence. Paper presented at the Annual Meeting of the Association for the Study of Higher Education, Tucson, AZ. 
Keegan, D. (2002). The future of learning: From e-learning to m-learning. Retrieved December 25, 2005, from http://learning.ericsson.net/leonardo/thebook/chapter4.html\#milearn.

Kerlinger, F. N., \& Lee, H. B. (2000). Foundations of Behavioral Research (4 ed.): Harcourt Inc.

Kettinger, W. J., \& Lee, C. C. (1997). Exploring a 'Gap' model of information services quality. Information Resources Management Journal, 8(3), 5-16.

Kettinger, W. J., Lee, C. C., \& Lee, S. (1995). Global measures of information service quality: A cross-national study. Decision Sciences, 26(5), 569-588.

Khalifa, M., Abidi, R., \&Limayem, M. (2002). Effects of Electronic Customer Relationship Management on Online Shopping Satisfaction. Pre-ICIS Meeting on French Speaking World IS Research.

Khalifa, M., \& Liu, V. (2002). Satisfaction with Internet-Based Services: the Role of Expectations and Desires. International Journal of Electronic Commerce, 7(2), $31-50$.

Khalifa, M., \& Liu, V. (2003). Determinants of Satisfaction at Different Adoption Stages of Internet-Based Services. Journal of the Association for Information Systems, 4(5), 206-232.

Khalifa, M., \& Shen, N. (2005, January 3-6). Effects of Electronic Customer Relationship Management on Customer Satisfaction: A Temporal Model. Paper presented at the Proceeding of the 38th Annual Hawaii International Conference on System Sciences (HICSS'05) Track 7.

Kim, G. M., \& Ong, S. M. (2005). An exploratory study of factors influencing m-learning success. Journal of Computer Information Systems, 46(1), 92-97.

Kim, J., \& Moon, J. Y. (1998). Design towards emotional usability in customer interfaces-trustworthiness of cyberbanking system interfaces. Interacting with Computers, 10, pp1-29.

Kim, S. Y., \& Lim, Y. J. (2001). Consumers' perceived importance of and satisfaction with Internet shopping Electronic Markets, 11(3), 1-7.

Kimery, K. M., \& McCard, M. (2002). Third-party assurances: mapping the road to trust in e-retailing. Journal of Information Technology Theory and Application, $4(2), 63-82$.

King, W. R., \& Epstein, B. J. (1983). Assessing information system value. Decision Sciences, 14(1), 34-45.

Klaussen, K. (2002). E-learning in PATS. Faculty of Information Technology, Mathematics and Electrical Engineering,Norwegian University of Science and Technology. 
Koch, H. C. H. (1994). Total Quality Management in Health Care (2 ed.): Longmans, London.

Kohlmeyer, J., \& Blanton, J. (2000). Improving IS quality. Journal of Information Technology Theory and Application, 2(1), 77-91.

Koller, M. (2001). Tool offers personalization on the fly. Internet Week, 857(6), 15.

Kruse, K. (2005). Using the Web for Learning: Advantages and Disadvantages. Retrieved December 25, 2005, from http://www.e-learningguru.com/articles/art1 9.htm

Kumar, D. D. (1995). Intelligent Educational Systems for Anchored Instruction. TECHTRENDS, 3(January/February), 33-35.

Kurbel, K., \& Hilker, J. (2002). Requirements for a mobile e-Learning Platform. Retrieved January 6, 2006, from http://www.euv-frankfurt-o.de/wi-www/

La, K. V., \& Kandampully, J. (2002). Electronic retailing and distribution of services: cyber intermediaries that serve customers and service providers. Managing Service Quality 12(2), 100-116.

Landers, P. (2002). From e-learning to m-learning. Retrieved December 25, 2005, from http://learning.ericsson.net/Mlearning2/project_one/thebook/chapter1.htm1

Larcker, D. F., \& Lessig, V. P. (1980). Perceived usefulness of information: A psychometric examination. Decision Sciences, 11(1), 121-134.

Laudon, K. C., \& Laudon, J. P. (1991). Management Information Systems: A Contemporary Perspective: Macmillan, New York, NY.

Lee, G. G., \& Lin, H. F. (2005). Customer perceptions of e-service quality in online shopping. International Journal of retail \& Distribution Management, 33(2), 161-176.

Legris, P., Ingham, J., \& Collerette, P (2003). Why Do People Use Information Technology? A Critical Review of the Technology Acceptance Model. Information \& Management, 40(5), 191-204.

Lehman, J. A., Van Wetering, J., \& Vogel, D. (1986). Mainframe and Microcomputer-based business graphics: What satisfies users? Information and Management, 10(3), 133-140.

Lehner, F., Nosekabel, H., \& Lehmann, H. (2002). Wireless e-learning and communication environment: WELCOME at the University of Regensburg. e-Service Journal, 2(3), 23-41.

Lehtinen, J. R., \& Lehtinen, O. (1982). Service quality: A study of quality dimensions. Unpublished working paper, Helsinki: Service Management Institute, Finland 
$O Y$.

Leung, C., \& Chan, Y. (2003). Mobile Learning: A New Paradigm in Electronic Learning. Paper presented at the 3rd IEEE International Conference on Advanced Learning Technologies (ICALT'03).

Levine, L. M. (2002). Campus-wide mobile wireless: Mobility and convergence. Syllabus, 5(2), 18-24.

Li, E. Y. (1997). Perceived importance of information system success factors: A meta analysis of group differences. Information \& Management, 32(1), 15-28.

Liao, Z., \& Cheung, M. T. (2002). based e-banking and consumer attitudes: an empirical study. Information and Management, 39(4), 283-295.

Liu, C., \& Arnett, K. (2000). Exploring the Factors Associated with Web Site Success in the Context of Electronic Commerce. Information \& Management, 38(1), 23-34.

Liukkunen, K. T. P., \& Laru, J. (2004). Developing new mobile services for the Universities -University students' conceptions of their needs for mobile tools for scaffolding learning activitie. Paper presented at the Ed-Media'04, Montreal, Canada.

Llosa, S., Jean-Louis C., \& Chiara, O. (1998). An Empirical Study of SERVQUAL's Dimensionality. The Service Industries Journal, 18(2), 16-44.

Lloyd-Walker, B., \& Cheung, Y. P. (1998). IT to support service quality excellence in the Australian banking industry. Managing Service Quality, 8(5), 350-358.

Loh, L., \& Venkatraman, N. (1992). Determinants of information technology outsourcing. Journal of Management Information Systems, 9(1), 7-24.

Lohse, G. L., \& Spiller, P. (1998). Electronic shopping. Communications of the ACM 41(7), 81-87.

Loiacono, E., Watson, R.T., \& Goodhue, D.L. (2002). WEBQUAL: a Measure of Website Quality. Paper presented at the In AMA Winter Conference, Austin, TX.

Loiacono, E., Watson, R. T., \& Goodhue, D. (2000). WebQual: ${ }^{\text {TM }}$ A Web Site Quality Instrument. University of Georgia, Athens, GA, 2000-126-0.

Lowey, S. (2003). MI Your Business. Training Journal - Continuing Professional Development for Trainers, 6(December), 26-30.

Lu, M., \& Yeung, W. (1998). A framework for effective commercial Web application development. Internet Research Journal, 8(2), 166-173. 
Luarn, P., \& Lin, H. (2004). A customer loyalty model for e-service context. Journal of Electronic Commerce Research, 4(4), 156-167.

Lucas, H. C. J. (1975). Performance and the use of an information system. Management Science, 21(8), 908-919.

Lynch, D., \& Lundquist, L. (1996). Digital Money: Wiley, New York, NY.

Ma, Q., Pearson, J., \& Tadisina, S. (2005). An Exploratory Study into factors of Service Quality for Application Service Providers. Information and Management, 42, 1067-1080.

Madu, C. N., \& Madu, A. A. (2002). Dimensions of e-quality. International Journal of Quality \& Reliability Management, 19(3), 246-258.

Maginnis, F., White, R., \& Mckenna, C. (2000). Customers on the move: $\mathrm{m}$-Commerce demands a business object broker approach to EAI. eAI Journal, November/December, 58-62.

Maish, A. M. (1979). User 's Behavior Toward His MIS. MIS Quarterly, 3(1), 39 - 52.

Maister, D. H. (1985). The service encounter: Managing employee/customer interaction in service business Lexington, MA: Lexington Books.

Malliou, E., Miliarakis, A., Stavros S., Sotiriou S.A., \& Startakis, M. (2002). The Ad-Hoc Project E-Learning Anywhere, Anytime [Electronic Version]. Retrieved August $\quad 25 \quad 2007$ from http://www2.ellinogermaniki.gr/publications/docs/Ad-Hoc Project.doc.

Margolies, J. M. (1988). When good service isn't good enough: Dallas, TX: Price Waterhouse.

Mauve, M., Scheele, N., \& Geyer, W. (2001). Enhancing synchronous distance education with pervasive devices. GI Jahrestagung, 2(1), 1117-1122.

McAlexander, J. H., Kaldenberg, D. O., \& Koenig, H. F. (1994). Service quality measurement. Journal of Health Care Marketing, 3, 34-40.

McCole, P. (2002). The role of trust for electronic commerce in services. International Journal of Contemporary Hospitality Management, 14(2), 81-87.

McDougall, G., \& Levesque, T. (2000). Customer Satisfaction with Services: Putting Perceived Value Into The liquation. Journal of Services Marketing, 14(5), 392-410.

McDougall, G. H. G., \& Levesque, T. J. (1994). A revised view of service quality dimensions: An empirical investigation. Journal of Professional Service Marketing, 11(1), 189-209.

McGhee, R., \& Kozma, R. (2001). New teacher and student roles in the technology-supported classroom. Paper presented at the annual meeting of the 
American Educational Research Association, Seattle.

McHaney, R., Hightower, R., \& Pearson, J. (2002). A validation of the end-user computing satisfaction instrument in Taiwan. Information \& Management $39(6), 503-511$.

McKenzie, J. (2001). The unwired classroom: Wireless computers come of age. Educational Technology, 10(4), 19-28.

McKinney, V., Yoon, K., \& Zahedi, F. (2002). The measurement of Webcustomer satisfaction: an expectation and disconfirmation approach. Information Systems Research 13(3), 279-296.

McMahon, M. (1997). Social constructivism and the world wide web-A paradigm for Learning. Paper presented at the ASCILITE, Curtin University, Perth.

Milrad, M. (2004). Mobile Learning: Challenges, Perspectives and Reality. Retrieved December 25, 2005, from http://21 st.century.phil-inst.hu/vol2 milrad.pdf

Mitchell, A., \& Doherty, M. (2003). mLearning support for disadvantaged young adults. Retrieved December 25, 2005, from http://intra.ultralab.net/ alice/dissemination/CAL_paper_2003.pdf

Mohr, L. A., \& Bitner, M. J. (1995). The role of employee effect in satisfaction with service transactions. Journal of Business Research, 32, 239-252.

Molla, A., \& Licker, P. S. (2001). E-commerce systems success: An attempt to extend and respecify the DeLone and McLean model of IS success. Journal of Electronic Commerce Success, 2(4), 1-11.

Money, R., \& Crotts, C. (2003). The Effect of Uncertainty Avoidance on Information Search, Planning and Purchases of International Travel Vacations. Tourism Management, 24(1), 191-202.

Morgan, R., \& Hunt, S. (1994). Relationship-Based Competitive Advantage The Role of Relationship Marketing in Marketing Strategy. Relationship-Based Competitive Advantage the Role of Relationship Marketing in Marketing Strategy, 46(3), 281-290.

Morrison, M., Jing, Su, O., \& Cai, L. (2001). Predicting Usage of the Internet for Travel Bookings: an Exploratory Study. Information Technology \& Tourism, $4(1), 15-30$.

Naismith, L., Lonsdale, P., Vavoula, G., \& Sharples, M. (2004). Literature Review in Mobile Technologies and Learning NESTA Futurelab Series, Report 11, 2004, United Kingdom.

Netemeyer, R. G., Bearden, W. O., \& Sharma, S. (2003). Scaling Procedures: Issues and Applications: Sage Publications. 
Niederman, F., Brancheau, J. C., \& Wetherbe, J. C. (1991). Information systems management issues for the 1990s. MIS Quarterly, 15(4), 475-500.

Nielsen, J. (1993). Usability Engineering: USA: Academic Press, Inc.

Nielsen, J. (1996). Usability Metrics: Tracking Interface Improvements. IEEE Software, 13(6), 12-28.

Nielsen, J. (2000). Designing Web Usability : The Practice of Simplicity. Indianapolis: New Riders.

Nielsen, J., \& Landauer, T. (1993). A mathematical model of the finding of usability problems. Paper presented at the ACM INTERCHF93, Amsterdam, The Netherlands.

Nielsen, J. (2000). New Devices Augur Decent mobile User Experience. Retrieved August 20, 2007, from http://www.useit.com/alertbox/20000917.html

Novak, T., Donna H., \& Yung, Y. F. (2000). Measuring the Customer Experience in Online Environments: A Structural Modelling Approach Marketing Science, 19(1), 22-42.

Nysveen, H., Methlie, B. \& Pedersen, E. (2003). Tourism Websites and Value-Added Services: The Gap Between Customer Preferences and Website Offerings. Information Technology \& Tourism, 5(2), 165-174.

Oku, M. (2001). High-level educational performance brings innovations to corporate culture. Retrieved November 15, 2005, from

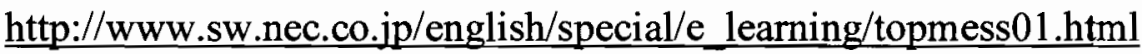

Oliver, B., \& Wright, F. (2002). The next big thing? Exploiting channels and handheld computers for student learning. Paper presented at the 11th Teaching and Learning Forum, Perth, Western Australia.

Oliver, C. (1998). Quality assuring an Internet-based service. Managing Service Quality, 8(2), 85-87.

Oliver, R. L. (1980). A Cognitive Model of the Antecedents and Consequences of Satisfaction Decisions. Journal of Marketing Research 17(September), 460-469.

Oliver, R. L. (1981). Measurement and evaluation of satisfaction process in retail settings. Journal of Retailing, 57, 25-48.

Oliver, R. L. (1993). A conceptual model of service quality and service satisfaction: Compatible goals, different concepts. Advances in Services Marketing and Management, 2, 65-85.

Oliver, R. L. (1997). Satisfaction: A Behavioral Perspective on the Consumer (1 ed.): New York: The McGraw-Hill Companies, Inc. 
Olson, M. H., \& Ives, B. (1981). User involvement in systems design: An empirical test of alternative approaches. Information and Management, 4(4), 183-195.

Open and Distance Learning Quality Council. (2005). A Definition of E-Learning. Retrieved December 25, 2005, from http://www.odlqc.org.uk/odlgc/n19-e.htm

Pallant, J. (2001). SPSS Survival Maual: A step by step guide to data analysis using SPSS for windows (Version 10) (1 ed.): Allen \& Unwin, Australia.

Palmer, A., \& Cole, C. (1995). Service marketing: Principles and practice: Englewood, Cliffs, NJ: Prentice-Hall.

Papanikolaou, K., \& Mavromoustakos, S. (2006). Critical Success Factors for the Development of Mobile Learning Applications. Paper presented at the 24th IASTED International Multi-Conference Internet and Multimedia Systems and applications Innsbruck,Austria.

Parasuraman, A., Zeithaml, V.A., \& Berry, L. L. (1985). A Conceptual Model Of Service Quality And Its Implications For Future Research. Journal of Marketing, 49(5), 41-50.

Parasuraman, A., Zeithaml, V. A, \& Berry, L. L. (1988). SERVQAL: A Multiple Item Scale For Measuring Consumer Perceptions Of Service Quality. Journal of Retailing, 64(4), 35-48.

Parasuraman, A., Berry, L. L., \& Zeithaml, V. A. (1991). Refinement and Reassessment of SERVQUAL Scale. Journal of Retailing, 67(4), 420-450.

Parasuraman, A., Berry, L., \& Zeithaml, V. (1993). More on Improving Service Quality Measurement. Journal of Retailing, 69(1), 140-147.

Parasuraman, A., Zeithaml, V., \& Berry, L. (1994). Alternative Scales for Measuring Service Quality: A Comparative Assessment Based on Psychometric and Diagnostic Criteria. Journal of Retailing, 70(3), 201-230.

Parasuraman, A., \& Zinkhan, M. (2002). Marketing to and Serving Customer Through the Internet: an Overview and Research Agenda. Journal of the Academy of Marketing Science, 30(4), 286-295.

Parasuraman, A. (2004). Assessing and Improving Service Performance for Maximum Impact: Insights from a Two-Decade-Long Research Journey. Performance Measurement and Metrics, 5(2), 45-52.

Parasuraman, A., \& Grewal, D. (2000). The impact of technology on the quality-value-loyalty chain: A research agenda. Journal of the Academy of Marketing Science, 28(1), 168-174.

Parasuraman, A., Zeithaml, V., \& Malhotra, A. (2005). E-S-QUAL A Multiple-Item Scale for Assessing Electronic Service Quality. Journal of Service Research, 7(3), 213-233. 
Paulsen, M. F. (2002). Teaching methods and techniques for computer-mediated communication. Retrieved December 25, 2005, from http://www.nettskolen.com/pub/artikkel.xsql?artid=126.

Pedhazur, E. J., \& Schmelkin, L. P. (1991). Measurement, design, and analysis: An integrated Approach: Lawrence Erlbaum Associates, Hillsdale, NJ.

Pehkonen, M., Turunen, H. (2003). Preliminary Guidelines for the Design of the Mobile Learning Activities and Materials. Retrieved December 25, 2005, from http://www.mindtrek.org/liitetiedostot/materiaalit_editori/75.doc.

Piccoli, G. (2001). Web-Site Marketing for the Tourism Industry: Another View. Cornell Hotel and Restaurant Administration Quarterly, December, 63-65.

Piccoli, G., Broham, M., Watson, R., \& Parasuraman, A. (2004). Net-Based Customer Service Systems: Evolution and Revolution in Web Site Functionalities. Decision Sciences, 35(3), 423-455.

Pitt, L. F., Watson, R. T., \& Kavan, C. B. (1995). Service quality: a measure of information effectiveness. MIS Quarterly, $179-187$.

Portioresearch.com. (2008). Mobile Fact book 2008 (1 ed.): Worldwide Mobile Market.

Pritchard, F. L. (1993). Quality of service in the retail drug setting: An examination of expectations and perceptions (perceived quality, service quality). Unpublished Doctoral dissertation University of Georgia.

Quinn, C. (2000). Mobile, Wireless, In-Your_Pocket Learning. Retrieved December 25,2005 , from $\mathrm{http} / / \mathrm{www}$. linezine.com/2.1/features/cqmmwiyp.htm

Raisch, W. D. (2001). The E-Marketplace: Strategies for Success in B2B E-commerce: McGraw-Hill.

Raju, J. S., Srinivasan, V., \& Lal, R. (1990). The effects of brand loyalty on competitive price promotional strategies. Management Science, 36(3), 276-304.

Rayman-Bacchus, L., \& Molina, A. (2001). Internet-Based Tourism Services: Business Issues and Trends. Futures, 33, 589-605.

Raymond, L. (1985). Organizational Characteristics and MIS Success in the Context of Small Business. MIS Quarterly, March, 37-52.

Reeves, C. A., \& Bednar, D. A. (1994). Defining quality: Alternatives and implications. Academy of Management Review, 19, 419-445.

Reichheld, F., \& Schefter, P. (2000). E-loyalty: your secret weapon on the web. Harvard Business Review, 78, 105-113. 
Reidenbach, R. E., \& Sandifer-Smallwood, B. (1990). Exploring perceptions of hospital operations by a modified SERVQUAL approach. Journal of Health Care Marketing, 10(4), 47-55.

Rekkedal, T. (2002). Enhancing the Flexibility of Distance Education - Experiences with a Learning Environment for Mobile Distance Learners. Retrieved January 6, 2006, from http://home.nettskolen.com/ torstein/m-learningCuttingEdge.doc.

Reynolds, J. (2000). The Completer E-commerce Book: Design, Build \& Maintain a Successful Web-based Business: CMP Media Inc.

Rice, M. (1997). What Makes Users Revisit a Web Site? . Marketing News, 3l(6), 12-13.

Riel, A. C. R., Liljander, V., \& Jurriens, P. (2001). Exploring consumer evaluations of e-services: A portal site. International Journal of Service Industry Management, 12(4), 359-377.

Robson, R. (2004). Mobile Learning and Handheld Devices in the Classroom. Retrieved December 25, 2005, from http://www.eduworks.com/Eduworks_new/Documents/Publications/Mobile learning_Handheld_Classroom.pdf

Rosen, E., \& Purinton, E. (2004). Website Design: Viewing the Web as a Cognitive Landscape. Journal of Business Research, 57, 787-794.

Ross, S., Donnelly, M., \& Dobreva, M. (2004). Digicult Emerging technologies for the Cultural and Scientific Heritage Sector: The XML Family of technologies. Retrieved 16, August 2006 from http://www.digicult.info/downloads/twr 2_2004_final low.pdf

Rowley, J. (1996). Retailing and shopping on the Internet. Internet Research. Electronic Networking Applications and Policy, 5(1), 81-91.

Rubin, J. (1994). Handbook of Usability Testing: New York: John Wiley \& Sons, Inc.

Russo C. L., E. D. H., \& DiVesta F. J. (1997). Relation Between Metacognition and Sales: Training for High Performance. Training Research Journal - The Science and Practice of Training, 3(2), 143-167.

Rust, R., \& Lemon, K. (2001). E-Service and the Consumer. International Journal of Electronic Commerce, 5(3), 85-101.

Rust, R. T., \& Oliver, R. L. (1994). Service quality: New directions in theory and practice: Thousand Oaks, CA: Sage Publications.

Rzewnicki, A. (2004). Rising demand lowers cost, Increasing usage of Wi-FI. Business Journal, In Depth: Triangle Tech News. 
Sanders, G. L., \& Courtney, S. F. (1985). A field study of organizational factors influencing DSS success. MIS Quarterly, 9(1), 77 - 89.

Santos, J. (2003). A model of virtual service quality dimensions. Managing Service Quality, 13, 233-246.

Sariola, J. (2001). What are the limits of academic teaching? In Search Of The Opportunities of Mobile Learning. Retrieved December 25, 2005, from http://ok.helsinki.fi/tekstit/Article.rtf

Saunders, M., Lewis, P., \& Thomhill, A. (2000). Research Methods for Business Student (2 ed.): London: Pearson Education Limited.

Savill-Smith, C., \& Kent, P. (2003). The use of palmtop computers for learning: A review of the literature. Retrieved January 6, 2006, from http://www.mlearning.org/docs/sept03.pdf.

Schwantz, G. D. (1996). Service quality in higher education: expectations and perceptions of traditional and non-traditional students. Unpublished doctoral dissertation, Texas Tech University, Lubbock, TX.

Seddon, P. B. (1997). A respecification and extension of the DeLone and McLean model of IS success. Information Systems Research, 8(3), 240-253.

Seddon, P. B. (1997). A respecification and extension of the DeLone and McLean model of IS success. Information Systems Research, 8(3), 240-253.

Sekaran, U. (2000). Research methods for business: a skill-building approach (4 ed.): NYC:John Wiley \& Sons, Inc.

Seppala, P., \& Alamaki, H. (2003). Mobile learning in teacher training. Journal of Computer Assisted Learning, 19(3), 330-335.

Seymour, D. T. (1992). On Q: Causing quality in higher education (1 ed.): New York: Macmil-lan.

Shahizan, H., \& Li, F. (2005). Evaluating the Usability and Content Usefulness of Web Sites: A Benchmarking Approach. Journal of Electronic Commerce in Organizations, 3(2), 46-67.

Shank, M. D., Walker, M., \& Hayes, T. (1995). Understanding professional service expectations: Do we know what our students expect of a quality education?. Journal of Professional Services Marketing, 13(1), 175-189.

Sharma, S. K., \& Kitchens, F. L. (2004). Web Services Architecture for M- Learning. Retrieved December 25, 2005, from http://www.ejel.org/volume-2/vol2-issuel/issuel-art2-sharma-kitchens.pdf

Sharples, M. (2000). The Design of Personal Mobile Technologies for Lifelong Learning. Computers and Education, 34(2), 177-193. 
Sharples, M. (2002). Disruptive Devices: Mobile Technology for Conversational Learning. International Journal of Continuing Engineering Education and Life-long Learning, 16(4), 28-35.

Sharples, M. (2003). Mobile and Ambient Learning. Paper presented at the Educational Technology Research Group Presentation, University of Birmingham.

Shemwell, D. J., \& Yavas, U. (1999). Measuring service quality in hospitals: scale development and managerial applications. Journal of Marketing Theory and Practice 7(3), 65-75.

Shim, M. K., \& Shim, S. J. (2001). Mobile computing in higher education: Faculty perceptions of benefits and barriers. Journal of Educational Technology Systems, 29(4), 345-354.

Shneiderman, B. (1998). Designing the User Interface: Strategies for Effective Human-Computer Interaction ( 3 ed.): Addison Wesley Longman.

Siau, K., Lim E.P., \& Shen, Z. (2003). Mobile Commerce: Promises, Challenges, and Research Agenda. Journal of Database Management, 14(1), 4-13.

Siau, K., \& Shen, Z. (2003). Mobile Communications and Mobile Services. Inter. J. Mobile Communications, 1(1/2), 3-14.

Sims, G. (2002). A pocket PC experience. Journal Educause Quarterly, 15(2), 69-72.

Sohn, C. A. (2000). Customer evaluation of Internet-based service quality and intention to re-use Internet-based services. Unpublished doctoral dissertation, Southern Illinois University, Carbondale, Illinois.

Song, J. H., \& Zinkhan, G. M. (2003). Features of web site design, perceptions of web site quality, and patronage behavior. Paper presented at the ACME

Sorensen, E. K., \& Takle, E. S. (2003). Collaborative knowledge building in Web-based learning. Assessing the quality of dialogue. Paper presented at the SITE 2003: Society for Information Technology and Teacher Education International Conference.

Spiller, P., \& Lohse, G. L. (1998). A classification of Internet retail stores. International Journal of Electronic Commerce, 2(2), 29-56.

Spiro, R. J., Feltovich, P. J., Jacobson, M. J., \& Coulson, R. L. (1991). Cognitive Flexibility, Constructivism, and Hypertext. Journal Educational Technology, May 1991, 24-33.

Spool, J., \& Schroeder, W. (2001). Testing Web Sites: Five Users is Nowhere Near Enough. Paper presented at the ACM CHI Conference on Human Factors in Computing Systems, Seattle, WA. 
Spreng, R. A., \& Mackoy, R. D. (1996). An empirical examination of a model of perceived service quality and satisfaction. Journal of Retailing. Journal of Retailing, 7(2), 201-214.

Spreng, R. A., \& Mackoy, R. D. (1996). An Empirical Examination of a Model of Perceived Service Quality and Satisfaction. Journal of Retailing, 72(2), 201-214.

Stahl, G., Sumner, T., \& Repenning, A. (1995). Internet Repositories for Collaborative Learning: Supporting both Students and Teachers. Paper presented at the Computer Supported Collaborative Learning Conference.

Stapleton, J. (1997). Information systems prototyping in practice. Journal of Information Technology, 14(1), 107-120.

Stone, A., \& Briggs J. (2002). How to use SMS effectively in m-learning. Paper presented at the European Workshop on Mobile and Contextual Learning, Birmingham, UK.

Stone, A., Briggs, J., \& Smith, C. (2002). SMS and interactivity-some results from the field, and its implications on effective uses of mobile technologies in education. Paper presented at the IEEE International Workshopon Wireless and Mobile Technologies in Education (WMTE 2002), Vaxjo, Sweden.

Storbacka, K., Strandvik, T., \& Grönroos, C. (1994). Managing customer relationships for profit: the dynamics of relationship quality. International Journal of Service Industry Management, 5(5), 21-38.

Stratmann, J. (2004). From Virtual University to Mobile Learning on the Digital Campus: Experiences from Implementing a Notebook-University. Retrieved December 25, 2005, from http://online-campus.net/DigitalCampus.pdf

Straub, D. W. (1989). Validating instruments in MIS. MIS Quarterly, 13(2), 146-169.

Strauss, H. (2004). Wireless Classrooms: Evolution or Extinction? . Retrieved December 25, 2005, from http://syllabus.com/print.asp?ID=8287

Su, Y., Chen, W., \& Wang, T. (2005). An Investigation of a Mobile Learning System in a Digital Filter Course. Paper presented at the Fifth IEEE International Conference on Advanced Learning Technologies Washington, DC, USA.

Surjadjaja, H., Ghosh, S., \& Antony, F. (2003). Perspectives Determining and assessing the determinants of e-service operations. Managing Service Quality, $13(1), 39-53$.

Swanson, E. B. (1974). Management information systems: appreciation and involvement. Management Science, 21(2), 178-188.

Swett, C. (2002). College students' use of mobile wireless-internet connections becomes more common. Knight Ridder Tribune Business News, Washington, 
$D C$.

Szymanski, M., \& Hise, T. (2000). E-Satisfaction: An Initial Examination. Journal of Retailing, 76(3), 309-322.

Tamahori, C. (2004). Mobile Technology and Tourism Presentation. Retrieved December 25, 2005, from www.shift.co.nz

Tao, E. (2003). Wireless network deployment and its impacts on teaching and learning-a case study of California State University Monterey Bay. Paper presented at the Syllabus, San Jose Marriott, Stanford University.

Taylor, R. A., \& Wang, M. S. Y. (1987, December 1987). An experimental study of user satisfaction with multiple dialog modes. Paper presented at the Eighth International Conference on Information Systems Research.

Taylor, S. A., \& Baker, T. L. (1994). An assessment of the relationship between service quality and customer satisfaction in the formation of consumers' purchase intentions. Journal of Retailing, 70(2), 163-178.

Taylor, S. A. (1997). Assessing regression-based importance weights for quality perceptions and satisfaction judgments in the presence of higher order and/or interaction effects. Journal of Retailing, 73(1), 135-159.

Taylor, S. A., \& Cronin, J. J. (1994). Modeling patient satisfaction and service quality. Journal of Health Care Marketing, 14(1), 34-44.

Thompson, S. H. T. (2001). Demographic and motivation variables associated with Internet usage activities. Internet Research: Electronic Networking Applications and Policy, 11(2), 125-137.

Thornton, P., \& Houser, C. (2001). Learning on the move: Vocabulary study via email and mobile phone SMS. Paper presented at the ED-MEDIA, Tampere, Finland.

Trifanova, A., \& Ronchetti M. (2003). A General Architecture for M-Learning (No. DIT-03-081): Informatica e Telecomunicazioni, University of Trento.

Trifonova, A. (2003). Mobile learning-review of the literature (No. DIT-03-009). Trento: University of Trento, Department of Information and Communication Technology.

Trifonova, A., Georgieva, E., \& Ronchetti, M. (2006). Has the Time for University's Mobile Learning Come? Determining Students' Readiness. Paper presented at the E-Learn 2006, Phoenix, AZ, USA.

United States Census. (2001). Retrieved November 5, 2005, from http://www.census.gov.

Uther, M. (2002). Mobile Internet Usability: What can 'Mobile Learning'Learn From the Past? Paper presented at the IEEE International Workshop on Wireless and Mobile Technologies in Education (WMTE'02). 
Valentine, E. (2004). Overview Study - e-Learning: The Market and New Zealand's Capability. New Zealand Trade and Enterprise.

Van Dyke, T. P., Kappelman, L. A., \& Prybutok, V. R. (1997). Measuring Information Systems Service Quality: Concerns on the Use of the SERVQUAL Questionnaire. MIS Quarterly, 21(2), 195-208.

Virzi, R. A. (1992). Refining the Test Phase of Usability Evaluation: How Many Subjects Is Enough? Human Factors, 34(4), 457-468.

Voss, C. (2000). Developing an e-service strategy. Business Strategy Review, 11(1), 21-33.

Vijayasarathy, L. R., \& Jones, J. M. (2000). Print and Internet catalog shopping: Assessing attitudes and intentions, Internet Research. Electronic Networking Applications and Policy, 10(3), 191 -202.

Wan, C. S. (2002). The Websites of International Tourist Hotels and Tour Wholesalers in Taiwan. Tourism Management, 23(2), 155-160.

Wang, M. (2003). Assessment of E-Service Quality via E-Satisfaction in E-Commerce Globalization. Retrieved December 25, 2006, from http://www.is.cityu.edu.hk/research/ejisdc/voll1/vllcl0.pdf.

Wang, Y.-S. (2003). Assessment of learner satisfaction with asynchronous electronic learning systems. Information \& Management, 41(2003), 75-86.

Webopedia.com. (2004). Definition of PDAs. Retrieved November 15, 2005, from http://www.webopedia.com/TERM/P/PDA.html.

Webster, C. (1989). Can consumers be segmented on the basis of their service quality expectations? Journal of Service Marketing, 3, 35-53.

Whitten, J. L., Bentley.L.D, \& Dittman, K. C. (2001). Systems Analysis and Design Methods (5 ed.): New York: McGraw-Hill.

Wilkin, C., \& Hewitt, B. (1999). Quality in a respecification of DeLone and McLean's IS. success model. Paper presented at the Proceedings of IRMA International Conference. Hershey.

Wolfinbarger, F., \& Gilly, C. (2003). eTailQ: Dimensionalising, Measuring and Predicting eTail Quality. Journal of Retailing, 79(1), 183-198.

Woodside, A. G., Frey, L.L., \& Daly, R.T. (1989). Linking Service Quality, Customer Satisfaction and Behavioral Intention. Journal of Health Care Marketing, 9(3), $5-17$

Woodside, A. G., Frey, L. L., \& Daly, R. T. (1989). Linking service quality, customer satisfaction, and behavioral intention. Journal of Health Care Marketing, 9(4), 5-17. 
Yang, X., Ahmed, Z., Ghingold, M., Boon, G., Mei, T. \& Hwa, L. (2003). Consumer Preferences for Commercial Web Site Design: An Asia-Pacific Perspective. Journal of Consumer Marketing, 20(1), 10-27.

Yang, Z. (2001). Measuring E-Service Quality And Its Linkage To Customer Loyalty. Unpublished Doctor of Philosophy, New Mexico State University, New Mexico.

Yang, Z., Peterson, R. T., \& Huang, L. (2001). Taking the Pulse of Internet Pharmacies. Marketing Health Services, Summer, 5-10.

Yang, Z., Cai, S., Zhou, Z., \& Zhou, N. (2005). Development and Validation of an Instrument to Measure User Perceived Service Quality of Information Presenting Web Portals. Information and Management, 42, 575-589.

Yang, Z., \& Jun, M. (2002). Consumer perception of e-service quality: from internet purchaser and non-purchaser perspectives. Journal of Business Strategies, 3(2), 122-137.

Yang, Z., Jun, M., \& Peterson, R. (2003). Measuring customer perceived online service quality. International Journal of Operations \& Production Management, 6(1), 27-41.

Yang, Z., Jun, M., \& T., P. R. (2004). Measuring customer perceived online service quality. International Journal of Operations \& Production Management, 24(11), 1149-1174.

Yang, Z., Shaohan, C., Zhouc, Z., \& Zhou, N. (2004). Development and validation of an instrument to measure user perceived service quality of information presenting Web portals. Information \& Management, 42(2005), 575-589.

Yin, R. K. (1994). Discovering the future of the case study method in evaluation research. Evaluation Practice, 15, 283-290.

Yin, R. K. (2003). Case study Research Design and Methods (3 ed.): California: Sage Publication.

Yuen, S., \& Yuen, P. K. (2003). PDAs as educational power tools. Journal of Tech Directions, 62(9), 14-17.

Zeithaml, V. (2002). Service Excellence in Electronic Channels. Managing Service Quality, 12(13), 135-138.

Zeithaml, V. A., Parasuraman, A., \& Berry, L. (1985). Problem and Strategies in Services Marketing. Journal of Marketing 49(1), 33-46.

Zeithaml, V. A. (1988). Consumer perceptions of price, quality, and value: a means-end model and synthesis of evidence. Journal of Marketing, 25(July), $2-22$. 
Zeithaml, V. A., Parasuraman, A., \& Berry, L. (1990). Delivering quality service: Balancing customer perceptions and expectations.

Zeithaml, V. A., Berry, L. L., \& Parasuraman, A. (1996). The behavioral consequences of service quality Journal of Marketing Research, 60(2), 31-46.

Zeithaml, V. A., Parasuraman, A., \& Malhotra, A. (2000). A Conceptual Framework for Understanding e-Service Quality: Implications for Future Research and Managerial Practice. MSI Monograph, Report \# 00-115.

Zeithaml, V. A., Parasuraman, A., \& Malhotra, A. (2002). Service Quality Delivery Through Web Sites: A Critical Review of Extant Knowledge. Academy of Marketing Science Journal, 30(4), 362 - 375.

Zhang, P., and von Dran, G. (2002). User Expectations and Rankings of Quality Factors in Different Web Sites Domains. International Journal of Electronic Commerce, 6(2), 9-33.

Zhu, F. X., Jr, W. W., \& Chen, I. (2002). IT-based services and service quality in consumer banking. International Journal of Service, 13(1), 69-90. 